\title{
THE USE OF ONLINE SOCIAL NETWORKS, FOR THE ACQUISITION AND DEVELOPMENT OF DIGITAL COMPETENCES
}

Conference Paper · March 2017

DOI: $10.21125 /$ inted.2017.1430

CITATIONS

0

3 authors, including:

\section{Ana Balula}

University of Aveiro

42 PUBLICATIONS 58 CITATIONS

SEE PROFILE
READS

37

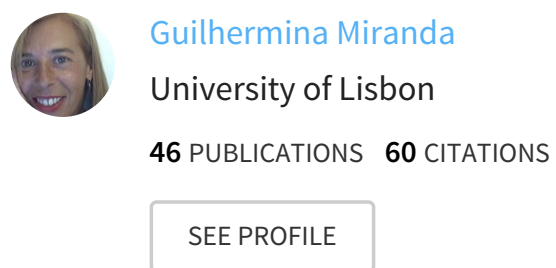

Some of the authors of this publication are also working on these related projects:

PhD segment View project 


\title{
THE USE OF ONLINE SOCIAL NETWORKS, FOR THE ACQUISITION AND DEVELOPMENT OF DIGITAL COMPETENCES
}

\author{
Anícia Trindade ${ }^{1}$, Ana Balula ${ }^{2}$, Guilhermina Miranda ${ }^{3}$ \\ ${ }^{1}$ Universidade de Aveiro (Portugal) \\ ${ }^{2}$ ESTGA - Universidade de Aveiro, CIDTFF (Portugal) \\ ${ }^{3}$ Universidade de Lisboa, Instituto de Educação (Portugal) \\ anicia.r.trindade@gmail.com, balula@ua.pt,gmiranda@ie.ulisboa.pt
}

\begin{abstract}
This ongoing study aims to characterize how the resettled refugees in Portugal use Online Social Networks (OSN). This understanding aims to create a practical guide to promote the development of digital competences, in order to support the inclusion in the host country. The participants will be resettled refugees that came to Portugal between 2006 and 2014. The study will also include the opinions of the leaders, as well as other key actors of relevance to the study (e.g. the High Commissioner for Migration in Portugal, the director of the observatory migration, and the UN agency's High Commissioner for refugees).

For this purpose, along with the selection and analysis of documents for the literature review, which will outline the theoretical and methodological assumptions underlying the study, a mixed design methodology will be held, based on the Design-based Research; it will be structured in four phases. Initially, we intend to characterize the participants and the host institution, as well as to identify the digital competences of the group of participants. Then, we shall proceed with the creation and application of the guide for the use of OSN, for the promotion and development of digital competences. In this second phase, a pilot of the application' Guide will be held. Subsequently, in the third phase of the project, we will apply the guide to the participants, and finally, in the fourth phase, we will improve and validate the implemented solutions. During the different stages of the research, diverse data collection techniques will be applied to address the problem understudy.
\end{abstract}

We will present a practical contribution about the use of OSN for development of digital competences, for the inclusion of resettled refugees in Portugal.

Keywords: Digital competences; Inclusion; Informal learning; Formal learning; Online Social Networks; Refugees.

\section{RESEARCH RELEVANCE}

Out of the 250 million migrants worldwide, 60 million are refugees who have fled their country of origin driven by war, violence and persecution and for fear of life-threatening. This refugee crisis has brought a great challenge to the host countries, regarding the effective inclusion and active participation of these people in the society activities of the host countries.

Different institutions in Portugal, governmental and non-governmental, have sought to respond to this challenge by developing activities that aim to contribute to the rapid inclusion of these people. The Portuguese Council for Refugees (PCR) ${ }^{1}$ is one of the Portuguese institutions that work in the field of refugee resettlement. The PCR was established on September 20, 1991, working closely with the United Nations High Commissioner for Human Rights (UNHCR) in Portugal, as well as with other public and private entities, seeking to support the consequences of the forced displacement of people in Portugal. According to PCR, the number of people seeking protection in Portugal is about 870 per year or 87 people per million inhabitants.

From 2006 to 2014 Portugal has received about 180 resettled refugees $^{2}$ who came from different countries $^{3}$. In January 2006, the PCR hosted, for the first time, a group of resettled refugees in

\footnotetext{
${ }^{1}$ See http://refugiados.net/1cpr/www/apresentacao.php.

2 "Refugee Reinstalled is a refugee who is first-served by another country. Refugee status is considered to be the act of a refugee moving to a second country that has agreed to receive it, usually for the refugee's personal interest in obtaining residence or citizenship in that country (particularly when there are elements of his or her family in that country), or Even when this country invites you to reside in that country" [19, p. 39].
} 
Morocco following the events that occurred in late 2005 in the Spanish enclaves of Ceuta and Melilla [1].

Resettlement is one of the solutions to the refugee situation, and consists in the selection and transfer of refugees from a first country of asylum where they are in precarious conditions, sometimes for generations, to a country that accepts to host and grant them a permanent right of residence [2]. Resettlement serves first and foremost to protect the lives and freedoms of refugees, and also contributes to some equity between the countries that have committed themselves to it, as is the case of Portugal and those that host the overwhelming majority of refugees in the world.

Mason and Buchmann [3] state that smartphones are an essential part of the kit for refugees as they travel. Coming from a different culture, different norms and values, contact with the country of origin is often done by the mobile devices that they use, through the use of Online Social Networks (OSN) [4]. Other studies have shown that refugees use OSN to play an active role in the host country by becoming involved and making their wishes and needs heard [4], [5]. Indeed, Godin and Doná [5, p. 60] mention that: "new social media enable refugees and diaspora members to exercise agency in managing the creation, production, and dissemination of their voices and to engage in hybrid (on- and offline) activism". Nevertheless, even after they have gone through a program of support and followup by the relevant entities and organizations, the inclusion of these actors in the host society is not always an absolute truth, and other strategy are claimed to assume and lead this role [1].

Taking in account that digital competences have been seen as transversal competences that contribute to the inclusion of individuals in the information society [6]-[9], we try to find out how the use of OSN by resettled refugees, which came to Portugal between 2006 and 2014, could contribute for the development of these competences, and promote their inclusion. Until now, we didn't find any studies that could help to understand how OSN can be used to promote the acquisition and development of digital competences and how the development of these competences contributes to the inclusion of refugees resettled in the host country.

Digital competences are one of the eight competences that are relevant in the scope of lifelong learning 4 and have been approached by different authors as fundamental within an active, participative and reflexive participation in the society in the era of innovation and digital information and communication [6], [8]-[11].

In this scenario and based on the arguments described above, we considered important to develop a Practical Guide to help resettled refugees to develop digital competences using OSN. More specifically, we seek to know how the use of the OSN can contribute to the acquisition and development of digital competences, and whether the development of these digital competences contributes to better inclusion of resettled refugees in the host country.

This way, our research questions are: To what extent can the use of OSN contribute to the inclusion of resettled refugees? How can OSN be used to promote the acquisition and development of refugee digital competences considered transversal competences?

\section{PURPOSE AND OBJECTIVES}

Taking into account the research questions, we sought to understand: (i) the characteristics and needs of the resettled refugees in order to understand their specificities; (ii) the challenges posed to their inclusion in the host society, for example their gaps in digital competences; and iii) the role that the use of OSN can play in the acquisition and development of digital competences, analysing the relevance of their use in the inclusion of these actors in the host society. Consequently, our research objectives are:

- To contribute to the knowledge about the use of OSN by resettled refugees.

- To identify the main gaps that resettled refugees have in terms of digital competence.

- To create, validate and apply a Guide for the Use of OSN in order to promote and develop digital competence.

- $\quad$ To check the influence of the use of the OSN Guide on the inclusion of resettled refugees.

For achieving these objectives, we start by defining the methodology, and the research plan.

\footnotetext{
${ }^{3}$ http://refugiados.net/1cpr/www/reinstalacao/estatisticas-reinstalacao2006-2014.pdf

4 Competence 1 and 2: communication in the mother tongue and communication in foreign languages; competence 3 : Mathematical competence and basic competences in science and technology; competence 4: digital competence; competence 5: learning to learn; competence 6: social and civic competence; competence 7: sense of initiative and entrepreneurship; competence 8: cultural awareness and expression [20].
} 


\section{DIGITAL LITERACY AND DIGITAL COMPETENCE - CONCEPTUALIZATIONS}

There are different concepts to designate the competences, abilities, attitudes and knowledge needed to deal with the digital environment, varying according to the underlying approach ([10]). By itself, the concept of literacy is a dynamic concept [10], [12] and the arrival of computers and multimedia communication has meant redefining the concept to adapt it to the information society.

According to the Portuguese dictionary Priberam ${ }^{5}$, by literacy is meant the ability to read and write, as well as the ability to perceive and interpret what is read. Literacy can still be seen as the ability to transform the spoken word into written text using the letters of an alphabet (code). On the other hand, "digital", according to the Portuguese dictionary Priberam 6 , is related to presenting data, results or indications in numerical form, as opposed to analogue (e.g., digital machine, digital clock). In a search in an English dictionary", "digital" consists of "(...) making use of computers and computerized technologies, including the Internet".

In his book on "Digital and media literacy: A plan of action", Hobbs [13] considers that the different approaches related to literacy and digital should not be seen as antagonistic but rather as concepts belonging to the same family. For the author [13], the concept of 'information literacy' is related to research and research skills, and 'media literacy' is related to the critical analysis of the information produced and disseminated by the media. In turn, digital literacy, according to the author, is associated with the ability to use computers, online social networks and the internet. Hobbs [13] presents a definition that is focused on "knowing how to use" - despite the fact that people need to be able to access, analyze and critically engage in the information they receive and send, to become critically involved in decision-making, and to maintain informed about the daily problems they face in relation to health, work, politics and leisure.

For Bawden [14], 'digital literacy' is the ability to understand and use information from various digital sources, thus being related to the technical skills and focus on the cognitive and socioemotional aspects of participating, interacting and producing information in a digital environment. For the European Commission [15], 'digital literacy' is seen as the necessary competences to be digitally literate, relying on the basic use of the internet and computers, reflecting an instrumental view of digital literacy. Regardless of the different approaches that the concepts of digital, informational and media literacy can assume, we think that the most important issue would be to discuss the valences that the new forms of literacy can assume in order to create convergence and consensus in digital terminology [12].

According to Ferrari [6] digital competence presents itself as a set of knowledge, skills, and attitudes) that are needed when using ICT and digital media to perform tasks, solve problems, to communicate, manage information, to collaborate, create and share content, and build knowledge. Since the digital media are constantly changing, the concept used to characterize the interaction of individuals with digital media should not be dependent on the instrumental component, inherent to the definitions proposed by some authors (for example [14], [16], [17]). It should also take into account the cognitive valences, attitudes and the reflexive and critical component in the construction of its definition. However, in the definition of digital competence proposed by Ferrari [6] and other authors [7], [9], [10], cognitive valences, attitudes and the reflexive and critical components are taken into account. For this reason, we consider that the concept of digital competence proposed by Ferrari [6] and later operationalized in the reference framework of digital competences proposed by this author [8] and subsequently revised and improved [11] meet the objectives of this research study.

The conceptualizations previously identified propose an understanding of the digital age which included the role of the individual in the interaction with it, and contributes, according to Ala-Mutka [9], to create an overview of the components that should integrate the concept of digital competence, as shown in Fig.1.

\footnotetext{
5 "Literacy", in Dicionário Priberam da Língua Portuguesa [online], 2008-2013, https://www.priberam.pt/dlpo/literacia [Retrieved on 27-11-2016]

6 "Digital" in Dicionário Priberam da Língua Portuguesa [online], 2008-2013 https://www.priberam.pt/DLPO/digital [Retrieved on 02-12-2016]

7 "Digital" in Dictionary.com [online] http://www.dictionary.com/browse/digital [Retrieved on 02-12-2016]
} 


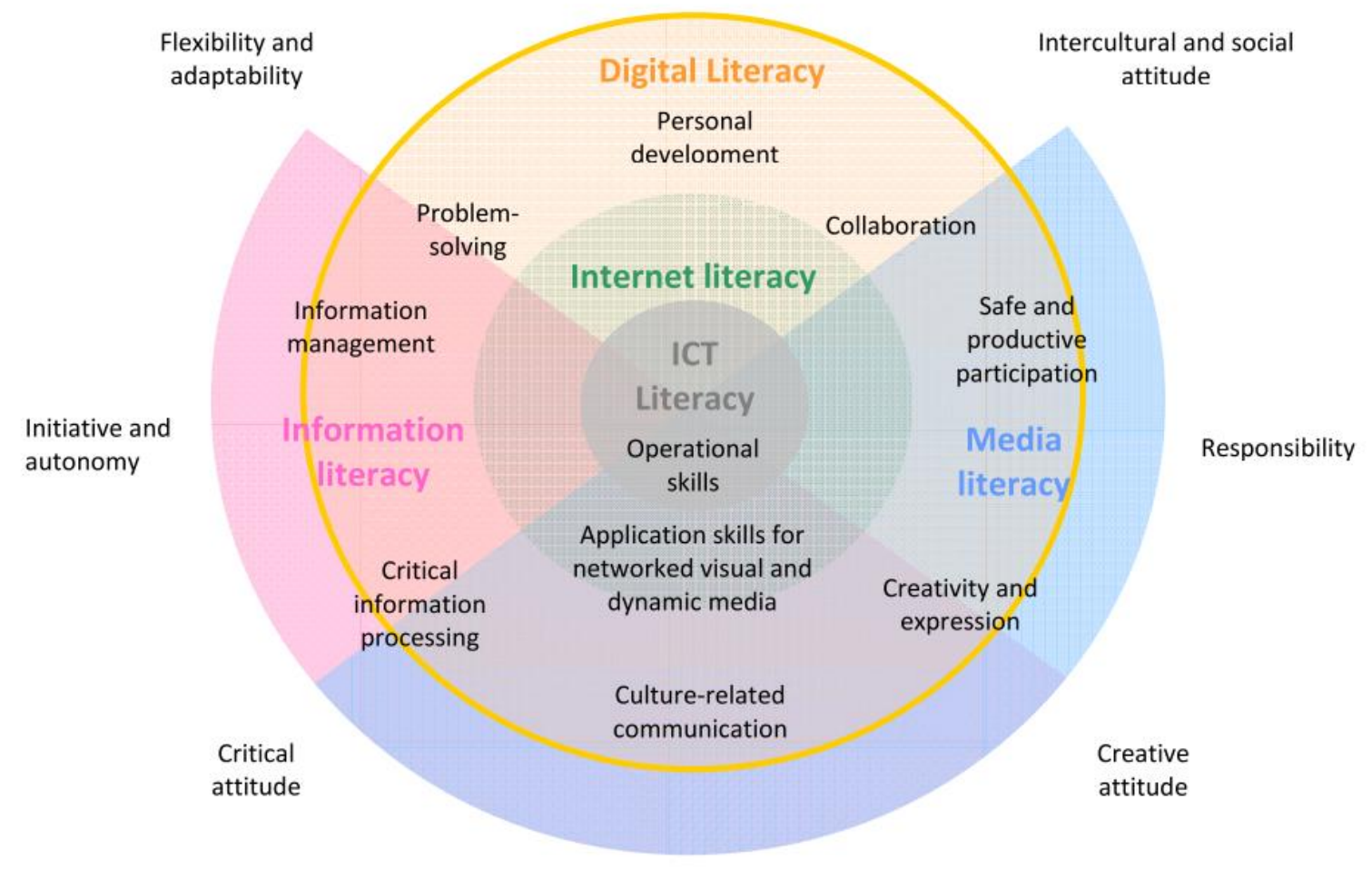

Fig.1- Mapping digital competence for the 21st century [9, p. 44].

\section{METHODOLOGY}

We considered that the present research can be included in the category of exploratory studies, because we did not found until now any study related to this subject. The approach selected was the Design-Based Research (DBR), considering that this study focuses on understanding a subject for which there are still no clear guidelines on its application and research. On the other hand, DBR allows us to create useful solutions for the contexts under study [18], giving the possibility to research solutions to improve this concrete context. Finally, the use of the DBR approach makes possible to investigate the problem under study in the natural context of the participants.

Our research plan, following the guidelines of the DBR methodology, will be developed in four phases, during which different activities of collection, analysis, reflection and treatment of data will be carried out. In a first phase, we intend to characterize the participants and the host institution, as well as to identify the participants' digital skills, knowledge and attitudes. In a second phase, supported by the analysis of the data collected in the first phase and the literature review, it will be possible to develop the Guide for the use of OSN in close collaboration with experts and other actors and, in this second phase, a pilot of the application of the Guide will be held. In a third phase, the guide will be applied to the group of resettled refugees. Finally, in a fourth phase, we will try to improve and validate the implemented solutions. Throughout the different phases of the research, diverse data collection techniques will be applied.

\section{RESEARCH PLAN}

The research plan was based on the definition of the problem to be researched and the outlined objectives, as well as on the theoretical framework. In the sub-sections below, a description of the phases of this study is put forward.

\subsection{Phase 1 - Participants Characterization}

In this phase, which we would like to have completed by the end of March 2017, we intended to characterize the resettled refugees regarding their socio-demographic data (nationality, gender, age, occupation, etc.) using a questionnaire that will be applied in person, but will also be available online. 
This questionnaire will include a section to collect information of the use of OSN by the refugees. In this phase, we will characterize the resettled refugees' digital competences. At this stage, a focus group will be held to analyse participant's perceptions of the identified gaps in what concerns digital competences. The idea is also to characterize the relevance that the participants confer to the use of OSN in their daily activities, in the scope of the development of digital competences, and to describe to what extent they consider that these competences contribute to their inclusion in Portugal.

In turn, the PCR will be characterized based on the information gathered in a semi-structured interview with its managers and the information available online (number of employees and volunteers and their areas of expertise, partnerships, projects developed and implemented; number of refugees who have already received support, number of resettled refugees ). In addition to the perspective of the leaders, some questions about their perception regarding the use of OSN for the development of digital competences will be included.

Some experts in the areas of digital competences and inclusion will also be interviewed to gather information as to their perception about the use of OSN to promote digital competences.

\subsection{Phase 2 - Guide construction and preliminary validation}

The Guide will be developed based on the OSN identified as the most used by the resettled refugees and their needs in this domain, with the input of specialists in the areas of digital competences and inclusion and also based on the literature review (Phase 1 of the study). These inputs will be collected in interview and questionnaires, as well as the application of the focus group technique. The Guide proposal will be further built using the updated DIGICOMP $2.0^{8}$ benchmark, version 2017, phase 2 for areas identified as gap competences. The gap competences will be developed taking in account the DIGCOMP 2.0 strategies as well as the competence levels (low, intermediate and advanced), and considering the examples of knowledge, skills and attitudes.

These strategies, developed in this preliminary phase Guide validation, will continue to be validated with a sample of resettled refugees of the PCR between 2006 and 2014, applying the iterative cycle proposed by Plomp [18].The duration and the number of the Guide application sessions with these participants will depend on the area or areas identified as relevant for the development of digital competences. In the implementation of these sessions, through a blended learning model, data will be collected through participant observation, and analysed resorting to the content analysis technique. It is also intended to obtain the perception of the refugees about the activities of the Guide for the development of digital competences through the focus group technique.

\subsection{Phase 3 - Guide application}

At this stage, participants will be organized into two groups (for example, by age, areas of interest, nationality...) in a non-probablistic sample. After the application of the guide within the first group, we will also want to analyse the perception of the participants regarding the utility of Guide in the development of digital competences. The results obtained with the application of Guide to the first group of refugees will contribute to the improvement of the application of Guide to the second group [18].

The implementation of Guide will be carried out in person (the number of sessions will be defined according to the areas of digital competences to be explored), as well as in online sessions (number of sessions per area to explore).

\subsection{Phase 4 - Guide assessment}

To conclude the empirical study, we will verify the influence of the Guide use and its contribution to the inclusion process from the point of view of the resettled refugees. The focus group technique will be applied to collect these data. The digital competences measurement scale applied in the first phase of the study will then be applied to check the digital competences of resettled refugees after the implementation of the Guide.

\footnotetext{
${ }^{8}$ DigComp 2.0 identifies the key components of digital competence in 5 areas: Information and data literacy; Communication and collaboration; Digital content creation; Safety; Problem solving. According with the website of European Commission, DigComp 2.0 was completed with the publication of DigComp 2.0 phase 1: the Digital Competence Framework for Citizens, and consists in the revision of the 21 descriptors and the vocabulary of the framework. The phase 2 of the framework will be completed by the first quarter of 2017, and includes 8 levels of learning outcomes and examples of the knowledge, skills and attitudes related to each competence. See https://ec.europa.eu/irc/en/digcomp/digital-competence-framework
} 
PCR leaders and experts in the area of digital competences will also be inquired about their perception regarding the results achieved by the resettled refugees, and the influence of the Guide application on the development of refugee digital competences and inclusion.

\section{CONCLUSIONS}

The described study is in its initial phase of development and, therefore, still without results. It is important to mention its relevance at the present time regarding the inclusion of resettled refugees in the host countries through the use of OSN, for the promotion of digital competences, that has been approached by different authors as one of the fundamental competences for active, and reflexive participation in a society strongly marked by innovation and technological development [6], [8]-[11].

In this scenario, we considered important to develop a Practical Guide to help resettled refugees to develop digital competences using OSN. More specifically, we seek to know how the use of the OSN can contribute to the acquisition and development of digital competences, and whether the development of these digital competences contributes to better inclusion of resettled refugees in the host country.

\section{ACKNOWLEDGEMENTS}

This study undertaking by the PhD in Multimedia in Education - University of Aveiro, Portugal has been a truly life-changing experience for me and it would not have been possible to perform without the support and guidance that I received from many people. First, I would like to thank to my scientific supervisor, Ana Balula and my scientific co-supervisor, Guilhermina Miranda, for all the support and encouragement, during the development of this research that is under progress. Without their guidance and constant feedback, it would not be possible to continue this study.

I greatly appreciate the collaboration and support of the Consulado Português para os Refugiados that allowed me to develop my study in this organization.

I am especially grateful to Universidade de Aveiro, and to Fundação para a Ciência e Tecnologia (FCT) that gave me the financial support, received through the Technology Enhanced Learning and Societal Challenges (TELSC) consortium, which involves three Portuguese Universities: Aveiro, Lisbon, and Minho Universities, to participate in this conference.

My deepest gratitude is directed to my eldest sister, my mother and my father who helped me believing and encouraging chasing and achieving my goals.

This article reports research developed within the PhD Program Technology Enhanced Learning and Societal Challenges, funded by Fundação para a Ciência e Tecnologia, FCT I. P. - Portugal, under contract \# PD/00173/2014.

\section{REFERENCES}

[1] T. N. da C. C. Matos, "A Inserção dos Refugiados Reinstalados no Mercado de Trabalho Uma etapa num processo de integração?," Universidade de Lisboa, 2011.

[2] Conselho Português para os Refugiados [CPR], "Reinstalação de Refugiados." [Online]. Available: http://refugiados.net/1cpr/www/reinstalacao.php.

[3] B. Mason and D. Buchmann, ICT4Refugees- A report on the emerging landscape of digital responses to the refugee crisis, Federal Mi. Bonn: Deutsche Gesellschaft für Internationale Zusammenarbeit (GIZ) GmbH, 2016.

[4] H. Charmarkeh, "Social media usage, Tahriib (migration), and settlement among Somali refugees in France," Refuge, vol. 29, no. 1, pp. 43-52, 2013. 
[5] M. Godin and G. Doná, “' Refugee Voices ,' New Social Media and Politics of Representation: Young Congolese in the Diaspora and Beyond," Refuge, vol. 32, no. 1, pp. 60-71, 2016.

[6] A. Ferrari, "Digital Competence in Practice: An Analysis of Frameworks," Luxembourg, 2012.

[7] J. Janssen, S. Stoyanov, A. Ferrari, Y. Punie, K. Pannekeet, and P. Sloep, "Experts' views on digital competence: Commonalities and differences," Comput. Educ., vol. 68, pp. 473-481, 2013.

[8] A. Ferrari, DIGCOMP: A Framework for Developing and Understanding Digital Competence in Europe. Sevilla: JRC-IPTS. Espanha: European Commission Joint Research Centre Institute for Prospective Technological Studies, 2013.

[9] K. Ala-Mutka, "Mapping digital competence: towards a conceptual understanding," 2011.

[10] R. Santos, J. Azevedo, and L. Pedro, "Literacia(s) digital(ais): definições, perspetivas e desafios Digital literacy (ies): definitions, perspectives and challenges," Rev. Media J., vol. 15, no. 27, pp. 27-44, 2015.

[11] R. Vuorikari, Y. Punie, S. Carretero, and L. Van Den Brande, DigComp 2.0: The Digital Competence Framework for Citizens. Update Phase 1: The Conceptual Reference Model, Luxembourg. Luxembourg, 2016.

[12] A. Gutierrez and K. Tyner, "Media Education, Media Literacy and Digital Competence," Comunicar, vol. 19, no. 38, pp. 31-39, 2012.

[13] R. Hobbs, Digital and media literacy: A plan of action, Aspen Inst., vol. 126, no. 3. United States of America: Aspen Institute, 2010.

[14] D. Bawden, "Origins and concepts of digital literacy," in Digital literacies: Concepts, policies and practices, 2008, pp. 17-32.

[15] European Commission, "Digital Literacy Report: a review for the i2010 elnclusion initiative, COMMISSION STAFF WORKING DOCUMENT," 2008.

[16] D. Bawden, "Information and digital literacies: A review of concepts," J. Doc., vol. 57, no. 2, pp. 218-259, 2001.

[17] J. M. P. Tornero and T. Varis, Media Literacy and New Humanism, UNESCO Ins. Moscow: UNESCO Institute for Information Technologies in Education, 2010.

[18] T. Plomp, "Educational Design Research: An introduction," in Educational Design Research: Part A: An introduction, T. Plomp and N. Nienke, Eds. 2013, pp. 11-51.

[19] C. de J. P. Esteves, "Educação intercultural e educação soka: Pontes de diálogo na intervenção com a comunidade de refugiados," Universidade de Lisboa, 2011.

[20] O. Hendrik and Y. Ohana, "The Eight Key Competencies for Lifelong Learning: an Appropriate Framework Withinwhichto Develop the Competence of Trainers in the Field of European Youthwork or Just Plainpolitics?," 2009. 